\title{
Impact of Mature Corporate Governance on Detective Role of Forensic Accounting: Case of Public Listed Companies in Oman
}

\author{
Ali Rehman ${ }^{1}$ and Fathyah Hashim² \\ ${ }^{1}$ Internal Audit Department, A'Sharqiyah University, Ibra, 400, Oman \\ ${ }^{2}$ Graduate School of Business, Universiti Sains Malaysia, 11800 Penang, Malaysia
}

\section{Abstract}

Organizational fraud is transpiring despite the availability of controls, regulatory directives, and governance guidelines. These controls, directives, and guidelines are only utilized as a compliance checkbox instead of being utilized to identify the control deficiencies and also to identify the maturity of corporate governance. Forensic accounting detective role is an activity which can be available within an organization that can be impacted and reformed by the mature corporate governance which can eventually assist organizations in the reduction of fraud and its related activities. Three

Corresponding Author:

Fathyah Hashim

fathashim@usm.my

Received: 5 August 2019 Accepted: 14 August 2019 Published: 18 August 2019

Publishing services provided by Knowledge

(c) Ali Rehman and Fathyah Hashim. This article is distributed under the terms of the Comms Attribution License, which permits unrestricted use and redistribution provided that the original author and source are credited.

Selection and Peer-review under the responsibility of the FGIC2019 Conference Committee. major constituents of mature corporate governance are the board of directors, audit and risk committee, and senior management or executive management. All three significant constituents are vital to the achievement of organizational objectives and providing satisfaction to shareholders. With the utilization of agency theory, this paper intends to identify the relationship between mature corporate governance and detective role of forensic accounting within public listed companies situated in Sultanate of Oman. The descriptive cross-sectional survey has been conducted with the utilization of quantitative method, and data has been analyzed by utilization of PLS-SEM. Result suggests that mature corporate governance has a significant direct impact on forensic accounting's detective role. In order to mitigate or eliminate fraud within organizations, it is highly recommended that organizations should have in-house forensic accounting detective role which can be strengthened with the mature corporate governance.

Keywords: mature corporate governance, good corporate governance, forensic accounting, detective role of forensic accounting.

\section{Introduction}

Organizations that suffered from fraud, such as Enron, WorldCom, Satyam, and Oman National Gas, provided different services and operated in different modes of sectors; however, these organizations have one thing in common; immature corporate governance (Pedneault, Rudewicz \& Silverstone, 2012; Pretorius, 2015) and non-availability of forensic accounting as in-house activity. Several works of literature are available 
which develops an emphasis on having corporate governance or good corporate governance and improving organizational internal assurance activities, but the literature which demonstrates the necessity of having mature corporate governance (MCG) and forensic accounting as in-house or internal assurance activity (Massie, 2012; Rehman \& Hashim, 2018) is not enough. With the high occurrences of fraud and its related activities, innovation is necessitated in the field of corporate governance and detection of fraud. This innovation can be termed as MCG and forensic accounting detective role (FAD) as part of governance management activities (Vinita, Joe \& Lee, 2008; Singleton \& Singleton, 2010)

In the current business environment, corporate governance is utilized as a compliance checkbox (Zhu, 2016) instead of being measured for its maturity (Wilkinson, 2014). It is a well-known fact that organizations cannot exist without the availability of corporate governance; however, it is the maturity of corporate governance which defines the organization and not the organizational maturity that defines the corporate governance (O'Connor \& Byrne, 2015). There are several instances available where newly formed organizations demonstrate the achievement of MCG, whereas more than decade-old organizations fail to achieve it. MCG assists organizations in achieving their goals and also identifies potential gaps between actual and planned performance. MCG obliges organizations to develop and implement strategies and policies which are targeted towards the realization of organizational objectives, mission, and vision.

Several committees and ordinances have been established after the prevalence of fraud. Few of the renowned committees and ordinances are Sarbanes-Oxley Act, Public Companies Accounting Oversight Board, and Committee of Sponsoring Organizations. However, fraud amounts and instances of fraud are increasing every year (ACFE, 2016; ACFE, 2014; ACFE, 2012). These ever-increasing frauds require services of an antifraud expert as conventional auditors denied the role of detecting fraud and label it as managements' responsibility (AICPA, 2013). This anti-fraud expert can be termed as FAD as they not only detect the fraud but also develop the controls so that similar or related event can be controlled in the future.

At the moment, FAD is considered as outside party which is called upon as and when required and only utilized as litigation support, divorce claim verification, insurance claim verification and expert witness (Singleton \& Singleton, 2010; Charles, Ramona, \& Suzanne, 2009). By utilization of FAD as an activity within the governance management system, will not only strengthen the controls but will also provide satisfaction to shareholders. Governance management is those who are directly responsible for the governance of organization such as BOD, ARC, SC, and the internal audit department 
(CMA, 2016). Agency theory defines the relationship where shareholders (principal) expect the agents (senior management) to act and make decisions in the principal's interest. However, the problem arises when the agent makes a decision which is not in favor of shareholders and creates an agency problem (Afza \& Nazir, 2014; Abdullah $\&$ Valentine, 2009). However, the inclusion of FAD in governance management system can eliminate or reduce the agency problems and related agency cost.

In Oman, the concept of corporate governance is relatively new. Codes of corporate governance are issued in 2016, whereas previous codes were issued in 2002 (Yllmaz, 2018). These newly developed codes oblige organizations to have basic requirements of corporate governance such as selecting of the board of directors (BOD, establishing audit and risk committee (ARC) and appointment and basic duties of senior management (SM). However, these codes do not define the composition and composure of BOD and ARC members, effectiveness of their meetings, and their impact on strategic planning. Similarly, the role of SM is also defined in a manner which fulfills the mere existence of SM but does not define the role which fulfills organizational commitment (Baatwah, Salleh, \& Ahmad, 2015). Moreover, studies related to corporate governance in Oman are very few, and there are no guidelines available which can demonstrate that applied corporate governance is mature or immature. Following Bhasin (2013), no country is safe from fraud and fraudsters, and organizations in Oman also suffered from fraud and fraud-related activities. Few of the reported fraud cases in Oman can be categorized as financial frauds and bribery and ranges from USD 39 million to 2.9 million pertaining to various sectors of business (Reuters, 2014; Reuters, 2011). This study proposes that MCG is an independent variable, and FAD is the dependent variable. MCG assists organizations in the achievement of goals, strategies, objectives, and accomplishment of the true meaning of corporate governance (Rehman \& Hashim, 2018).This study highlights the importance of FAD not only as fraud finder but as part of the governance management system, which can be directly impacted by MCG. This study also attempts to combine and incorporate relevant empirical research and literature to extend the intended potentials of MCG on FAD, particularly in public listed companies in Oman. Corporate governance is dependable and impacted upon by many factors (Wilkinson \& Plant, 2012); however, this study is aiming towards the identification of mature corporate governance impact over a fraud detecting activity. Therefore, this study is unique in its way by testing the impact and relationship of MCG, which is a system on FAD, which is an activity and both MCG and FAD can be available within the organization. 


\section{Literature Review}

This section reviews related and relevant literature on the theoretical and empirical research related to MCG and FAD. This section discusses the definition, concepts, and prior studies. Firstly, there is a review of existing literature in the field of MCG, which provides an understanding of the foundation and its related concepts. Moreover, this chapter also identifies gaps in the literature. This chapter also presents the framework for this study.

\subsection{Mature corporate governance}

There are several works of literature available which term corporate governance as good, immature, or poor; however, very few literatures is available, which demonstrates the measurement of corporate governance. It is the measurement of corporate governance, which defines that corporate governance is mature or immature. This measurement also defines where the organization stands and where they want to be and also identifies the planning gaps. In order to fully understand the concept of MCG, it is necessary to explain corporate governance, good corporate governance and scales require for the measurement of corporate governance.

\subsubsection{Corporate governance}

Corporate governance is a system which defines and directs organizational policies, strategies, goals, and objectives. Corporate governance can also be defined as a system which directs and controls activities with positive business perception and integrity (Baghel \& Yadav, 2009). There could be plenty of definitions for corporate governance; however, all will be defining the same purpose (Fernando, 2009). Corporate governance itself cannot function and is dependable upon its governance management. Governance management is those who are directly responsible for the governance of organization such as BOD, ARC, SM, and internal audit (Hermanson \& Rama, 2016). Nevertheless, corporate governance offers a platform, via developed codes, where organizations are obliged to provide information and to act and follow local laws and regulation. It is up to the organization that how they utilize corporate governance such as either utilize as a compliance checkbox (Zhu, 2016) or measure it towards its maturity (Rehman \& Hashim, 2018). 
Organizations which demonstrate good corporate governance provide better results for their shareholders and can attract more potential business (Pintea \& Fulop, 2015). Similarly and keeping the same concept; organizations which provide poor corporate governance end up in losses and face difficulty towards attracting new businesses and customers. It can be asserted that corporate governance cannot guarantee the good or poor performance of the organization, but it can develop a culture of integrity, controls, and compliances by impacting activities within the organization.

\subsubsection{Good corporate governance}

Good corporate governance guarantees sustainable, enduring growth and development. Essential requirement towards the attainment of good corporate governance includes determined BOD and ARC, accurate and reliable financial reporting, protecting the interest of minority shareholders and implementation of laws and regulations. Good corporate governance consents organizations to realize their optimum efficiency and effectiveness, mitigate fraud and exploitation of power and provide a system of responsibility and accountability (Homayara, Md. Jahangir, Saeed, \& Sawlat, 2008; Hashim, Mahadi \& Amran, 2015).

It is worth mentioning that corporate governance does not follow the life cycle approach and as mentioned earlier; it is entirely dependent upon the organization that how they want to utilize corporate governance and to consider it as good or poor corporate governance. Oso and Semiu (2012) provide the following principle in Table 1 for good corporate governance:

As mentioned earlier, corporate governance can be a compliance checkbox, or it can be measured to identify its maturity and its impact over the organization. Good corporate governance is a culture and provides an environment of stability, obligation, accountability, fairness, comprehensibility, and effectiveness. However, the measurement of good corporate governance is required to ensure that a positive and honest relationship exists between the organization and its stakeholders (Kocmanova \& Simberova, 2012).

\subsubsection{Attributes of mature corporate governance}

It is the maturity of the corporate governance within the organization which needs to be identified enabling the evaluation of the good corporate governance as good corporate governance does not offer organized roadmap towards implementation and also do not define further measurable steps (Massie, 2012; Bramont, 2012). Organizations are 
TABLE 1: Principles of Good Corporate Governance.

\begin{tabular}{|c|c|}
\hline Principles & Description \\
\hline $\begin{array}{l}\text { Shareholders rights and } \\
\text { equitable treatment }\end{array}$ & $\begin{array}{l}\text { Shareholders should have fundamental rights. These rights should be } \\
\text { properly articulated and should be available in articles of association and } \\
\text { organizations website. } \\
\text { All shareholders should be treated equally irrespective of the number of } \\
\text { shares held by them. }\end{array}$ \\
\hline Stakeholders' interest & $\begin{array}{l}\text { Protection of stakeholders' interest should be available in the } \\
\text { organization's policies and should be properly approved. }\end{array}$ \\
\hline $\begin{array}{l}\text { Role and responsibility } \\
\text { of the board of } \\
\text { directors }\end{array}$ & $\begin{array}{l}\text { The board should be formed with roles and responsibilities. Board should } \\
\text { have expertise and knowledge related to business, accounting and } \\
\text { auditing. }\end{array}$ \\
\hline $\begin{array}{l}\text { Ethical behavior and } \\
\text { integrity }\end{array}$ & $\begin{array}{l}\text { This is the essence of good corporate governance. Directors and } \\
\text { executives of organizations should perform with ethics and integrity. They } \\
\text { should avoid conflict of interest and perform the duty of care. }\end{array}$ \\
\hline $\begin{array}{l}\text { Disclosure and } \\
\text { transparency }\end{array}$ & $\begin{array}{l}\text { Corporate governance requires that proper disclosures are made in the } \\
\text { financial statements and transparency is followed in all transactions. All } \\
\text { related parties transactions should be properly disclosed along with } \\
\text { board resolutions. }\end{array}$ \\
\hline \multicolumn{2}{|c|}{ Source: Oso and Semiu (2012) } \\
\hline
\end{tabular}

obliged to follow and develop sound principles of corporate governance as it is the requirement of stakeholders, regulators, and it is also the necessity to avoid organizations' failures. In order to define what precisely organizational governance necessitates and how organizations should implement and monitor these sound governance principles has led towards the establishment of organizational own governance structures, systems, and process towards achievement of organizational MCG (Wilkinson, 2014).

There is no common or defined structure for MCG measurement (Roberta, Sanjai \& Brian, 2008; Massie, 2012). MCG is a term available in researches conducted by companies outside of the academic publishing and distribution channels; these are often referred to as "grey literature." These researches are conducted by professionals, audit firms and governmental bodies established for this specific purpose. Furthermore, the trivial focus is provided by academic literature in the field of MCG (Massie, 2012; Wilkinson, 2014; Wilkinson \& Plant, 2012; Rehman \& Hashim, 2018).

In the absence of MCG, organizations can face complex situations towards conducting assessments related to organizational strategy and necessitated management assurances. Moreover, isolated managements' assurance practices are not only related to national or business culture barriers but also related to the achievement of MCG (Brender, Yzeiraj \& Fragniere, 2015). In accordance with O'Connor and Byrne (2015), governance predicts organizational maturity and not organizational maturity predicts governance. In light of this argument, it can be asserted that MCG also defines the maturity of the organization as a whole. 
Regulator, which in case of Oman is Capital Market Authority, is also responsible for measuring the governance maturity of organizations allowing them to look further and away from contextual issues of corporate governance and focus on the maturity aspects of the organization (O'Connell, 2016). Regulators might be required by law to perform MCG for organizations, however it is the responsibility of organization to develop and customize framework based on their requirements (Portella, 2014) to measure and achieve MCG as it provides a capability for tracking organizational progress and also provides methodology for establishing criteria for providing relevant, accurate and reliable information on the efficiency of current governance process (Bahrman, Manchanda, Roth \& Mendes, 2012). MCG assists in planning, organizing, evaluating, managing and monitoring organizations. Advancement of governance could be jeopardized if MCG is not identified and established (Wilkinson, 2014).

MCG can also be explained as corporate governance indicative system which is based on the core and fundamental areas of responsibility of the BOD, ARC, and SM. MCG assists organizations in identifying their situation on corporate governance by assessing organizational governance capabilities across several constituents (Deloitte, 2010; Allais, Roucoules \& Reyes, 2016). MCG as a system can support organizations in better understanding of their actions which can be considered necessary towards efficiency and effectiveness of organizational governance. Following comparison in Table 2 is available between mature and non-mature governance organizations' attributes (Lockhart, 2011):

\subsubsection{Measurement of mature corporate governance}

Anything which cannot be measured cannot be improved and controlled (Harpham, Grant, \& Thomas, 2002; Berenson, 2016). Keeping a similar notion, corporate governance, or good corporate governance cannot perform well unless it is measured. Measurement of corporate governance eventually leads toward MCG (Rehman \& Hashim, 2018). For the measurement of MCG, the following features are considered necessary and presented in Table 3 (Wilkinson, 2014):

In accordance with Table 3, there are three significant attributes towards the measurement of MCG and they can also be considered as major constituents. These constituents are defined in the following sections. Constituents of MCG can also include remuneration and compensation committee (Wilkinson, 2014); however, it is a very new committee (CMA, 2016) and has very minimal impact on the achievement of MCG. 
TABLE 2: Comparison between Mature and Non-Mature Governance.

\begin{tabular}{|c|c|}
\hline Non-Mature Governance & Mature Governance \\
\hline $\begin{array}{l}\text { Non independent and personally-held } \\
\text { ownership among family members only }\end{array}$ & $\begin{array}{l}\text { Independent directors, associated board } \\
\text { members and diversified ownership }\end{array}$ \\
\hline Non constitutional and statutory arrangement & $\begin{array}{l}\text { Strategies and policies are developed. } \\
\text { Minority shareholders rights are protected. }\end{array}$ \\
\hline $\begin{array}{l}\text { Centrally regulated management with no } \\
\text { segregation of duties among management } \\
\text { and those charged with governance }\end{array}$ & $\begin{array}{l}\text { Board of Directors manages the governance } \\
\text { and proper segregation of duties exists } \\
\text { between organizational management and } \\
\text { governance management. }\end{array}$ \\
\hline Intuitive and informal decision making & $\begin{array}{l}\text { Decisions are properly documented, made at } \\
\text { board level and are followed up for } \\
\text { implementation }\end{array}$ \\
\hline $\begin{array}{l}\text { Decision and responsibilities are taken at } \\
\text { individual levels }\end{array}$ & Decision is made as a group \\
\hline $\begin{array}{l}\text { Non-formal meetings and as and when } \\
\text { required. }\end{array}$ & $\begin{array}{l}\text { Board and management meets regularly with } \\
\text { agenda being circulated well in advance }\end{array}$ \\
\hline Non-recoding or minuting meeting minutes & $\begin{array}{l}\text { Meetings are formally conducted and are also } \\
\text { minuted. }\end{array}$ \\
\hline $\begin{array}{l}\text { Only one person and or entirely unified } \\
\text { leadership }\end{array}$ & $\begin{array}{l}\text { Board approved the policies and governance } \\
\text { decisions. These are implemented via CEOs. }\end{array}$ \\
\hline Un-stable and regular changing strategies & $\begin{array}{l}\text { Formal planning, evaluation and proper } \\
\text { control against strategies, plans and } \\
\text { objectives }\end{array}$ \\
\hline $\begin{array}{l}\text { Policies are not approved at appropriate } \\
\text { levels and no formal approvals }\end{array}$ & $\begin{array}{l}\text { Written policies, effective and efficient } \\
\text { delegations of authorities and formal } \\
\text { procedures }\end{array}$ \\
\hline
\end{tabular}

TABLE 3: Necessary Features for the Measurement of Mature Corporate Governance.

$\begin{aligned} & \text { Feature } \\ & \text { Attributes }\end{aligned}$
$\begin{aligned} & \text { Attributes are the features which can be associated with the area of } \\ & \text { specialization, such as board of directors, audit and risk committee and } \\ & \text { senior or executive management. } \\ & \text { Levels of maturity demonstrate that, where attributes stand. Usually, it } \\ & \text { ranges from immature to mature. } \\ & \text { Levels of maturity } \\ & \text { Criteria are the narrative form which links attributes with levels of } \\ & \text { maturity. It describes where organization stands in terms of maturity and } \\ & \text { also provides gaps analysis towards the potential achievement of MCG }\end{aligned}$
Source: Wilkinson (2014)

\subsubsection{Board of directors}

Board of directors (BOD) is the representatives of shareholders (Fernando, 2009). BOD is appointed by the shareholders to run the operations of the organization by developing policies and governance guidelines. BOD is also responsible for providing long term vision and strategy for the organization (Ganesan, Hwa, Jaaffar, \& Hashim, 2017). BOD 
is required to work closely with the senior management for the implementation of organizational strategies, policies, governance guidelines, and objectives (CMA, 2016; Mohd-Sanusi, Rameli, Omar \& Ozawa, 2015).

There is no standard rule for the formation of BOD; however, it is recommended that members of BOD should possess knowledge of finance, business, organizational environment and its competitive environment (Mohd-Sanusi et al., 2015). Formation of BOD directly impacts the fraud that could occur in the organization as there could be many situations arising towards the conflict of interest, biased decisions, and erroneous judgments. Moreover, the majority of BOD members should be independent (Bansal \& Sharma, 2016). BOD forms many committees within its members, such as audit and risk committee (ARC) and remuneration committee (CMA, 2016). BOD is required to have its charter or terms of reference, which defines its roles and responsibilities. These charters should be aligned with organizational vision and objectives and should be reviewed regularly (Mohd-Sanusi et al., 2015). Charter of BOD obliges them to work towards the best interest of the organization and also defines their authorities, limitations, and restrictions on decisions (Fernando, 2009).

BOD should not involve themselves in every day's operations of organizations (Leonard, 2010). Meetings of BOD should be convened regularly and with regular intervals. BOD meetings are majorly aimed for the approval of financial statements and also towards decisions on the issues related to organizational strategies (CMA, 2016). Meeting agenda should be informed before the date of the meeting and should be accompanied by the material information (OECD, 2009). All meetings of BOD should be recorded in the shape of minutes, and their decisions should be properly implemented (Bahrman et al., 2012). BOD meetings should be more concentrated for the organizational development, strategy formation, and development of objectives and goals (Bahrman et al., 2012). Decisions related or taken in the BOD meeting should be circulated to all employees as this procedure is essential to support transparency and it also develops trusts among employees (Zakaria, 2012; Mohd-Sanusi et al., 2015).

\subsubsection{Audit and risk committee}

Audit and risk committee (ARC) is formed from the members of BOD and should compromise of members who possess the knowledge of audit, finance, accounts, and fraud (Bahrman et al., 2012). Majority of ARC members should be independent members and should operate under their own charter or terms of reference (Rehman \& Hashim, 2018). ARC is one of the major contributors to the achievement of MCG. ARC ensures 
that internal controls are in place and they are implemented properly by SM. Although, internal controls are approved by BOD but it is the duty of ARC to provide their opinion for the implementation of organizational policies and internal controls (OECD, 2009; Bahrman et al., 2012; Wilkinson, 2014; Mohd-Sanusi et al., 2015).

There is no hard and fast rule for the number of members for ARC; however, the minimum number of members should be three (CMA, 2016). Efficiency and effectiveness of ARC are dependent upon the number of meetings (Shir, 2013). The ARC should meet as and when required but is required to meet at least four times a year and should have minimum one separate meeting with the internal auditor and external auditor. ARC meetings should be recorded and minuted. ARC is also required to provide an opinion about the implementation of internal control in the financial statements of the organization (Abbot, Park \& Parker, 2000; CMA, 2016).

ARC reduces the element of fraud and assists in the achievement of MCG (Wilkinson, 2014). It is one of the obligations of ARC to discuss internal and external audit findings with SM. These discussions provide support to internal and external auditors and at the same time, obliges SM to implement the recommendations proposed by these auditors (Laux \& Laux, 2009). The ARC should ensure that organizational strategies are attainable and risk-free; moreover, the element of fraud is mitigated for the attainment of MCG (Bentley-Goode, Newton \& Thompson, 2017)

\subsubsection{Senior management}

Senior management (SM) plays a major role in the implementation of policies which are approved by BOD (Mohd-Sanusi et al., 2015). SM is the major driver for the achievement of good corporate governance which can eventually lead towards the attainment of MCG (Rehman \& Hashim, 2018). Corporate governance creates segregation of duties between the SM and BOD. In the past, there were many organizations where chairman $B O D$ and chief executive officer of the company was the same person thus heaving organizations towards fraud and fraudulent activities (Keasey, Thomson \& Right, 2012)

BOD appoints SM for the fulfillment of the duties and achievement of organizational vision, mission, goals, and objectives (Korine \& Gomez, 2014). SM is a group of people who are directly responsible for the performance of the organization. SM includes chief executive officer, chief operating officer, and chief financial officer. SM should review organizational strategy every three years (Bentley-Goode, Newton \& Thompson, 2017) to identify potential gaps between objectives of the organization (Mohd-Sanusi et al., 2015) which can create hindrance in the achievement of MCG. 
SM must implement recommendations of ARC, internal auditors, and external auditors. SM should also review the internal controls regularly to identify their applicability and to identify whether they are capable of achieving MCG or they require enhancement. SM develops tone at the top and also develops a culture of honesty and integrity. Furthermore, and in order to avoid fraud and its related activities, SM plays significant role by implementing anti-fraud strategies which are usually provided by forensic accounting (Bhasin, 2013).

\subsection{Detective role of forensic accounting}

The emergence of forensic accounting is because of continuous and rigorous frauds (Leonard, 2010). Forensic accounting can also be categorized as the innovation towards fraud detection and prevention (Vinita, Joe \& Lee, 2008). Forensic accounting is classified into two main functions, namely (a) preventive role of forensic accounting and (b) detective role of forensic accounting (FAD). History is filled with events where frauds are occurred due to poor corporate governance and due to the lack of fraud detection activities (Singleton \& Singleton, 2010; Siregar \& Tenoyo, 2015). Furthermore, it is the FAD that provided the tools and controls to detect fraud in the cases of WorldCom and Enron (Bhasin, 2013). The FAD is an activity that can be available within an organization and as part of governance management. Governance management is entities directly associated with the governance of an organization such as BOD, ARC, SM, and internal auditors (Hermanson \& Rama, 2016). It is worth mentioning that regulatory and monitoring auditors (internal auditors) have denied the role for the detection of fraud (AICPA, 2017; IIA 2016; Salem, 2012; Francine, 2018) and FAD is not included in codes of corporate governance developed by many authorities including recent codes issued in Oman by CMA (2016). In this scenario, only organizational management will remain responsible for the detection and mitigation of fraud, but for doing so they require expertise and this expertise can be categorized as a FAD. In the current organizational scenario, FAD is only utilized as litigation expert, divorce settlement expert, insurance claim verifier and is called as and when required (Odelabu, 2016; Adrian, Lawrence \& Lee, 2009; Gee, 2014; Nigrini, 2012). Only limited literature is available where FAD is considered as an activity which can impact corporate governance (Enofe, Ekpulu \& Ajala, 2015; Siregar \& Tenoyo, 2015) however, these literature are again emphasizing on the availability of FAD as the external party and not as part of governance management. FAD assists organizations in setting up internal controls in order to identify the fraud promptly and also assists in mitigating the fraud risks. 
FAD assists organizations in developing accounting controls which are based on the instances of actual fraud occurring, therefore, these controls are considered as very useful towards fighting and eliminating fraud (Singleton \& Singleton, 2010; Leonard, 2010)

\subsection{Corporate governance in Oman}

Concept of corporate governance in Oman is not very old. New codes of corporate governance are introduced in 2016, whereas previous codes were issued in 2002 (CMA, 2016). In recent years there are several researches available related to the corporate governance in Oman; however, none of the researches is related to the aspect of MCG. Available studies explain the concept of corporate governance in accordance with financial reporting timelines, compliance with accounting standards, relationship of corporate governance with financial performance, comparison of codes between GCC countries and potential challenges faced towards implementation of new codes of corporate governance (Ellen, 2002; Al-Shammari, Brown, \& Tarca, 2008; Baydoun, Maguire, Ryan, \& Willett, 2013; Shehata, 2015; Baatwah, Salleh, \& Ahmad, 2015; Sanyal \& Hisam, 2018; Yllmaz, 2018). No studies are found concerning the Omani market regarding how corporate governance can be considered as mature or immature, and FA can be considered as part of the governance management system. There is a total of 115 companies listed in the Muscat Stock Market. With regards to the fraud in Oman, there is no data available demonstrating the number of frauds occurrences, however, following ACFE (2016), there are 6\% organizations that suffered fraud losses during 2014 to 2016. There are few other reported fraud incidents available in Table 4, which demonstrate following about the fraud losses in Oman:

TABLE 4: Fraud Cases Reported in Oman.

Name of Organization
Bank Muscat
Oman Oil Company
Topaz Company

Topaz Company

Nature of Fraud
Theft
Corruption
Bribery

\begin{tabular}{|l|}
\hline Amount of Fraud \\
\hline USD 39 million \\
USD 8 million \\
USD 2.9 million \\
\hline
\end{tabular}

\begin{tabular}{|c|}
\hline Source \\
\hline Reuters (2013) \\
\hline Reuters (2014a) \\
\hline Reuters (2011) \\
\hline
\end{tabular}

In accordance with Table 4, fraud cases belong to various organizations and have different nature of fraud; however, all are impacting the organizations' repute, distorting the confidence of shareholders and also demonstrates the immature corporate governance. FAD provides controls and tools that can detect fraud promptly. FAD also provides lesson learned reports which provide future fraud mitigation controls. The FAD is impacted by the policies which are approved by BOD and implemented by 
SM. In a current business scenario, FAD is not reporting to ARC; however, if FAD is considered as part of the governance management system, then ARC can play a significant role towards its independence, discussion of reports and implementation of recommendations.

\subsection{Underlying Theory}

Theory applicable and explaining the relationship between MCG and FAD is agency theory. This theory can be defined as shareholders delegating some responsibilities to a team of experts while keeping in mind that they will perform best for the success of their organizations while resolving the conflict of interest and other related problems (Afza \& Nazir, 2014). Agent or agency is hired by one or more persons called the principals. Agents act under a contract and are compensated by the principal to achieve desired outcomes for the principal. Because the agent is acting on behalf of the principal, the principal gives away decision-making authority to the agent. Hired agents such as SM, $B O D$, and $A R C$ are directly responsible for the implementation of corporate governance and the achievement of mature corporate governance (Bahrman et al., 2012). Agents are responsible for the delivery of results and safeguarding the interest of shareholders, and this interest can only be protected by achieving MCG and utilization of means which can be categorized as a FAD. Till date, there is no specific role for FAD defined as an agent, although FAD completely qualifies the criteria of becoming an agent and can provide services to the principal. Moreover, FAD can also protect agency cost and agency conflict by eliminating financial statement fraud and occupational fraud. MCG impacts FAD in shape of approved policies, processes, and by allowing FAD to become part of the governance management system.

\section{Methodology}

To identify the relationship between MCG and FAD, quantitative method of research is applied with a descriptive cross-sectional survey design. Public listed companies in Oman are utilized as a unit of analysis. Five-point Likert scale logic was being used for this study ranging from strongly disagree to agree strongly. Questions were distributed into different sections of BOD, ARC, SM, and FAD. Each section explained the definition and purpose of the research. Furthermore, and in agreement with the study of Meeran, Amjad, Ansari, Ansari, and Latif (2018), a census sampling technique is adopted since the population is small, so the contribution of all 115 companies was 
taken into consideration.Questions for this research are adopted and adapted from previous studies and are presented in Table 5. These questions are utilized for the measurement of MCG and FAD. It is recommended to take questionnaires as adopting or adapting as it assists in linking the studies to all other related studies and researches and also enhances the effectiveness and efficiency for the researcher (Korb, 2016). Questions in Table 5 are comprehensive and cover all the significant elements of MCG. Organizations cannot exist with the basic requirements of corporate governance (Butt, 2012); however, it is the effectiveness of BOD, ARC, and SM which enhances the corporate governance towards the attainment of MCG. Effectiveness can be achieved with well-defined structures, efficient meetings whose decisions are taken based on the well-informed reporting, and decisions are properly implemented. Terms of reference or charter also play a vital role in the efficiency and effectiveness of BOD. Questions which are related to FAD dealt with the accounting and internal control system specifically linked with fraud detection. Moreover, respondents are asked to identify whether FAD can only be utilized for uncovering diverted and unfocused fraudulent practices. These questions assist in identifying the organizational viewpoint about FAD and its related impact towards shaping the accounting and internal controls.

TABLE 5: Adapted and Adopted Questions.

\begin{tabular}{|c|c|c|c|}
\hline Question for Study & $\begin{array}{l}\text { Adopt/ } \\
\text { Adapt }\end{array}$ & Original Question & Source \\
\hline \multicolumn{4}{|c|}{ Mature Corporate Governance - Board of Directors } \\
\hline $\begin{array}{l}\text { In my company, there is a } \\
\text { defined management } \\
\text { structure supported by } \\
\text { organization charts for all } \\
\text { roles. }\end{array}$ & \multicolumn{2}{|l|}{ Adopt } & $\begin{array}{l}\text { Mohd-Sanusi, Rameli, } \\
\text { Omar, and Ozawa (2015) }\end{array}$ \\
\hline $\begin{array}{l}\text { My company's Board of } \\
\text { Directors meetings are } \\
\text { held regularly and minuted, } \\
\text { with actions noted in } \\
\text { accordance with new } \\
\text { codes of corporate } \\
\text { governance issued by } \\
\text { Capital Market Authority }\end{array}$ & Adapt & $\begin{array}{l}\text { Board's meetings were } \\
\text { held regularly and minuted, } \\
\text { with actions clearly noted. }\end{array}$ & $\begin{array}{l}\text { Mohd-Sanusi, Rameli, } \\
\text { Omar, and Ozawa (2015) }\end{array}$ \\
\hline $\begin{array}{l}\text { My company's Board of } \\
\text { Directors has defined } \\
\text { Terms of Reference which } \\
\text { are updated periodically }\end{array}$ & Adapt & $\begin{array}{l}\text { Board have clearly defined } \\
\text { job descriptions and set } \\
\text { performance targets which } \\
\text { are updated annually. }\end{array}$ & $\begin{array}{l}\text { Mohd-Sanusi, Rameli, } \\
\text { Omar, and Ozawa (2015) }\end{array}$ \\
\hline $\begin{array}{l}\text { My company's Board of } \\
\text { Directors ensures that } \\
\text { strategic planning is in line } \\
\text { with the organization's } \\
\text { objectives. }\end{array}$ & Adapt & $\begin{array}{l}\text { Board have clearly defined } \\
\text { job descriptions and set } \\
\text { performance targets which } \\
\text { are updated annually. }\end{array}$ & $\begin{array}{l}\text { Mohd-Sanusi, Rameli, } \\
\text { Omar, and Ozawa (2015) }\end{array}$ \\
\hline \multicolumn{4}{|c|}{ Mature Corporate Governance - Audit and Risk Committee } \\
\hline
\end{tabular}




\begin{tabular}{|c|c|c|c|}
\hline Question for Study & $\begin{array}{l}\text { Adopt/ } \\
\text { Adapt }\end{array}$ & Original Question & Source \\
\hline $\begin{array}{l}\text { My company's Audit and } \\
\text { Risk Committee meetings } \\
\text { are held regularly and } \\
\text { minuted, with actions } \\
\text { noted in accordance with } \\
\text { new codes of corporate } \\
\text { governance issued by the } \\
\text { Capital Market Authority. }\end{array}$ & Adapt & $\begin{array}{l}\text { Board's meetings were } \\
\text { held regularly and minuted, } \\
\text { with actions clearly noted. }\end{array}$ & $\begin{array}{l}\text { Mohd-Sanusi, Rameli, } \\
\text { Omar, and Ozawa (2015) }\end{array}$ \\
\hline $\begin{array}{l}\text { My company's Audit and } \\
\text { Risk Committee discuss the } \\
\text { pervasiveness of audit } \\
\text { finding/ recommendations } \\
\text { in audit reports with senior } \\
\text { management. }\end{array}$ & Adapt & $\begin{array}{l}\text { Fraud issues are being } \\
\text { discussed seriously during } \\
\text { the meeting. }\end{array}$ & $\begin{array}{l}\text { Mohd-Sanusi, Rameli, } \\
\text { Omar, and Ozawa (2015) }\end{array}$ \\
\hline $\begin{array}{l}\text { My company's Audit and } \\
\text { Risk committee ensure that } \\
\text { strategic planning is in line } \\
\text { with the organization's } \\
\text { objectives. }\end{array}$ & Adapt & $\begin{array}{l}\text { Strategic planning has a } \\
\text { clear relationship with the } \\
\text { organization's objectives. }\end{array}$ & $\begin{array}{l}\text { Mohd-Sanusi, Rameli, } \\
\text { Omar, and Ozawa (2015) }\end{array}$ \\
\hline \multicolumn{4}{|c|}{ Mature Corporate Governance - Senior Management } \\
\hline $\begin{array}{l}\text { In my company, there is } \\
\text { strategic planning lasting } \\
\text { three years or more }\end{array}$ & Adopt & & $\begin{array}{l}\text { Mohd-Sanusi, Rameli, } \\
\text { Omar, and Ozawa (2015) }\end{array}$ \\
\hline $\begin{array}{l}\text { My company's strategic } \\
\text { planning has a clear } \\
\text { relationship with the } \\
\text { organization's objectives. }\end{array}$ & Adopt & & $\begin{array}{l}\text { Mohd-Sanusi, Rameli, } \\
\text { Omar, and Ozawa (2015) }\end{array}$ \\
\hline $\begin{array}{l}\text { Senior Management of my } \\
\text { company seriously views } \\
\text { corrective actions as an } \\
\text { avenue for improvements }\end{array}$ & Adopt & & $\begin{array}{l}\text { Mohd-Sanusi, Rameli, } \\
\text { Omar, and Ozawa (2015) }\end{array}$ \\
\hline \multicolumn{4}{|c|}{ Forensic Accounting - Detective Role } \\
\hline $\begin{array}{l}\text { My company has updated } \\
\text { accounting systems to } \\
\text { detect fraud }\end{array}$ & Adapt & $\begin{array}{l}\text { My company has changed } \\
\text { accounting or internal } \\
\text { control system to detect } \\
\text { fraud }\end{array}$ & Siregar and Tenoyo (2015) \\
\hline $\begin{array}{l}\text { My company has updated } \\
\text { internal control systems to } \\
\text { detect fraud }\end{array}$ & Adapt & $\begin{array}{l}\text { My company has changed } \\
\text { accounting or internal } \\
\text { control system to detect } \\
\text { fraud }\end{array}$ & Siregar and Tenoyo (2015) \\
\hline $\begin{array}{l}\text { Forensic accounting in my } \\
\text { company can only be used } \\
\text { to uncover diverted/ } \\
\text { unfocused fraudulent } \\
\text { practices. }\end{array}$ & Adopt & & $\begin{array}{l}\text { Enofe, Ekpulu, and Ajala } \\
\text { (2015) }\end{array}$ \\
\hline
\end{tabular}

Respondents are asked to answer 16 questions, which also comprise three demographics questions. Respondents for this study are those who can respond on behalf of the organization and includes members of the BOD, members of ARC, SM, internal auditors, and company secretaries. Data is collected by utilization of Internet-based tool, and analysis is performed by usage of Statistical Package for Social Science (SPSS) and 
Partial Least square and Structural Equation Modeling (PLS-SEM). Assessment of the measurement model in PLS-SEM is required which is made for internal consistency and reliability by utilizing composite reliability (CR). It can also be defined as measuring internal consistency, convergent validity via indicator reliability and average variance extracted (AVE) and measuring discriminant validity with Heterotrait-monotrait (HTMT) ratio (Henseler, Ringle, \& Sarstedt, 2015). Regarding AVE, CR, and discriminant validity, acceptable values are defined by Ramayah, Cheah, Chuah, Ting, and Memon (2016) and presented in following Table 6:

TABLE 6: Rules of Thumb for Model Evaluation- Measurement Model Analysis Using PLS-SEM.

\begin{tabular}{|c|c|c|}
\hline Assessment & Name of Index & Acceptable Value \\
\hline Internal consistency & Composite reliability & Composite reliability $\geq 0.70$ \\
\hline $\begin{array}{l}\text { Indicator reliability/Factor } \\
\text { Loadings }\end{array}$ & Indicator Loading & $\begin{array}{l}\text { Loadings }>0.7,0.6,0.5 \text { is } \\
\text { adequate. Values below } 0.4 \\
\text { should be deleted }\end{array}$ \\
\hline Convergent validity & $\begin{array}{l}\text { Average Variance Extracted } \\
\text { (AVE) }\end{array}$ & $\begin{array}{l}\text { The average variance extracted } \\
\text { (AVE) should be higher than } \\
0.50 \text {. Indicators below } 0.5 \\
\text { should be deleted. }\end{array}$ \\
\hline Discriminant validity & HTMT Criterion & $\begin{array}{l}\text { HTMT - all values should be } \\
\text { below } 0.85\end{array}$ \\
\hline
\end{tabular}

After the assessment of the measurement model, the next step is to assess the structural model in PLS-SEM. Assessment of the structural model includes measurement of collinearity, path coefficient, R-square, and Q-square (Hair, Hult, Ringle, \& Sarstedt, 2017). Table 7 defines the rule of thumb for the assessment of structural model:

TABLE 7: Rules of Thumb for Model Evaluation- Structural Model Analysis Using PLS-SEM.

\begin{tabular}{ll|l}
$\begin{array}{l}\text { Assessment } \\
\text { Collinearity }\end{array}$ & $\begin{array}{l}\text { Name of Index } \\
\text { VIF (Variance inflator factor) }\end{array}$ & $\begin{array}{l}\text { Acceptable Value } \\
\text { Multi-Collinearity occurs in a } \\
\text { model when VIF values for } \\
\text { specific indicators are } 5 \text { and } \\
\text { above } \\
\text { p-value }<0.01 \\
\text { t value }>2.33 \text { (one-tailed) }\end{array}$ \\
\hline Path Coefficient & Path Coefficient & $\begin{array}{l}0.26 \text { - Substantial } \\
0.13-\text { Moderate }\end{array}$ \\
\hline R-square & Coefficient of determination & $\begin{array}{l}\text { O.O2- Weak } \\
\text { A value larger than zero }\end{array}$ \\
\hline Q-square & Stone Geisser Q2 predictive & $\begin{array}{l}\text { indes that exogenous } \\
\text { constructs have predictive } \\
\text { relevance over the endogenous } \\
\text { construct }\end{array}$ \\
& &
\end{tabular}




\section{Results}

Out of 115 organizations, $96 \%$ responded. Response rate is in agreement with the other studies where census sampling is applied with response rate less than $100 \%$ (Meeran, Amjad, Ansari, Ansari, \& Latif, 2018; Janulyte, Aleksejuniene, Puriene, Peciuliene, \& Benzian, 2014; Samim, Aleksejuniene, Zed, Salimi, \& Emperumal, 2013; Yeboah, Kwafoa, \& Amoah, 2017; Butt \& Shams, 2013). After careful analysis of the received data, three respondents are identified who do not provide the answers for all of the questions and considered as missing data. This missing data is deleted, and analysis is performed on the remaining 107 respondents, which comprises $93 \%$ of the total population.

Table 8 defines the demographic profile of 107 respondents. Majority of the respondents are male and representing $96 \%$ of the population, whereas female respondents are only $4 \%$. With regards to the qualification, the majority of respondents are professionally qualified, such as a chartered accountant, public accountant, certified internal auditors, and certified risk assessors. The second-highest category of respondents pertains to Master qualification followed by bachelors, others, and certified fraud examiners respectively. Other qualification includes those qualifications which were not listed in the questionnaire such as lawyer degree and chartered secretary certifications. For the role or position in the organization, $71 \%$ of respondents belong to the category of senior management, the second-highest category of respondents are members of ARC which is $16 \%$ followed by the board of directors.

TABLE 8: Demographic Profile of Respondents.

\begin{tabular}{l|l|c|c}
\hline Category & Description & $\begin{array}{c}\text { Number of } \\
\text { Respondents }\end{array}$ & \%age \\
\hline Gender & Male & 103 & 96 \\
\hline Highest Qualification & Female & 4 & 4 \\
& CA/ CPA/ MIPA/ CIA/ CRMA & 51 & 48 \\
\hline & $\begin{array}{l}\text { CFE or other fraud-related } \\
\text { education }\end{array}$ & 3 & 3 \\
\hline & Masters & 36 & 34 \\
\hline & Bachelors & 13 & 12 \\
\hline Role/ Position in & Others & 7 & 4 \\
\hline Organization & Board of Director & 14 & 13 \\
\hline & Audit and Risk Committee & 17 & 16 \\
\hline & Senior Management & 73 & 71 \\
\hline
\end{tabular}


Assessment of the measurement model is conducted in PLS-SEM with the rule of thumb defined by Ramayah et al., (2016), which are presented in Table 6. AVE and CR of MCG are 0.500 and 0.903 , respectively whereas AVE and CR of FAD are 0.575 and 0.793 respectively. These values are presented in Table 9 below: Furthermore, for HTMT ratio, the value is below 0.85 , and it can be asserted that discriminant validity is established (Ramayah et al., 2016).

TABLE 9: Average Variance Extracted and Composite Reliability.

\begin{tabular}{|c|c|c|c|}
\hline Variable and Questions & $\begin{array}{l}\text { Outer } \\
\text { Loading }\end{array}$ & AVE & $\mathrm{CR}$ \\
\hline \multicolumn{4}{|l|}{ Mature Corporate Governance } \\
\hline $\begin{array}{l}\text { In my company, there is a defined management structure } \\
\text { supported by organization charts for all roles. }\end{array}$ & 0.665 & 0.5 & 0.903 \\
\hline $\begin{array}{l}\text { My company's Board of Directors meetings are held } \\
\text { regularly and minuted, with actions noted in accordance with } \\
\text { new codes of corporate governance issued by Capital } \\
\text { Market Authority }\end{array}$ & 0.561 & & \\
\hline $\begin{array}{l}\text { My company's Board of Directors has defined Terms of } \\
\text { Reference which are updated periodically }\end{array}$ & 0.758 & & \\
\hline $\begin{array}{l}\text { My company's Board of Directors ensures that strategic } \\
\text { planning is in line with the organization's objectives }\end{array}$ & 0.791 & & \\
\hline $\begin{array}{l}\text { My company's Audit and Risk Committee meetings are held } \\
\text { regularly and minuted, with actions noted in accordance with } \\
\text { new codes of corporate governance issued by Capital } \\
\text { Market Authority }\end{array}$ & 0.607 & & \\
\hline $\begin{array}{l}\text { My company's Audit and Risk Committee discuss the } \\
\text { pervasiveness of audit finding/ recommendations in audit } \\
\text { reports with senior management. }\end{array}$ & 0.567 & & \\
\hline $\begin{array}{l}\text { My company's Audit and Risk committee ensure that } \\
\text { strategic planning is in line with the organization's objectives. }\end{array}$ & 0.734 & & \\
\hline $\begin{array}{l}\text { In my company, there is strategic planning lasting three } \\
\text { years or more }\end{array}$ & 0.699 & & \\
\hline $\begin{array}{l}\text { My company's strategic planning has a clear relationship } \\
\text { with the organization's objectives. }\end{array}$ & 0.766 & & \\
\hline $\begin{array}{l}\text { Senior Management of my company seriously views } \\
\text { corrective actions as an avenue for improvements }\end{array}$ & 0.766 & & \\
\hline \multicolumn{4}{|l|}{ Forensic Accounting - Detective Role } \\
\hline $\begin{array}{l}\text { My company has updated accounting systems to detect } \\
\text { fraud }\end{array}$ & 0.809 & 0.575 & 0.793 \\
\hline $\begin{array}{l}\text { My company has updated internal control systems to detect } \\
\text { fraud }\end{array}$ & 0.915 & & \\
\hline $\begin{array}{l}\text { Forensic accounting in my company can only be used to } \\
\text { uncover diverted/ unfocused fraudulent practices. }\end{array}$ & 0.500 & & \\
\hline Source: Authors' own work & & & \\
\hline
\end{tabular}

In accordance with Table 9, all the requirements of the measurement model are meeting the criteria and assessment of structural model can be performed. For the assessment of the structural model, evaluation of collinearity, path coefficient, R2, and 
Q2 was conducted. For the collinearity assessment, the result suggests that the value of VIF is 1. Multi-Collinearity occurs in a model when VIF values for specific indicators are 5 and above (García-Carbonell, Martín-Alcázar, \& Sánchez-Gardey, 2015); hence, there is no issue of multicollinearity. Values of R2 and Q2 are 0.210 and 0.093 , respectively, which are also meeting the acceptance criteria. The R2 defines an area of related construct variance that is explained by the model, and acceptable values are 0.02-0.12 as weak, 0.13-0.25 as moderate and above 0.26 as substantial (Hair et al., 2017). The Q2 is verified to establish the model's predictive relevance for endogenous constructs. Q2 values larger than zero indicate the model's predictive relevance for the endogenous constructs under consideration (Hair et al., 2017). Values of outer loading and $\mathrm{R}^{2}$ are also presented in Figure 1.

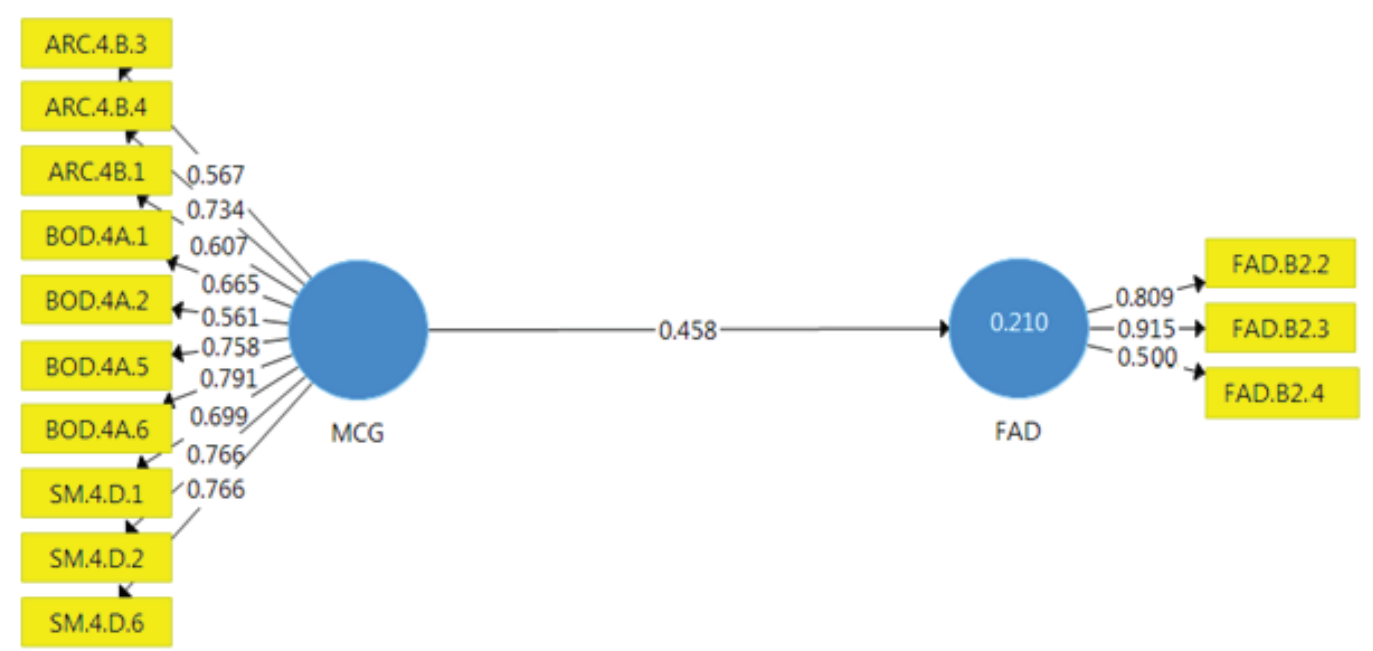

Figure 1: Outer Loading and $\mathrm{R}^{2}$ (Source: Authors' own work).

For the significance of Direct Effects- Path Coefficients, bootstrapping was utilized via smart PLS for 107 samples with the application of 5000 samples. Path coefficient is measured to ascertain a level of significance related to the direct effects. Rule of thumb for a level of acceptance related to path coefficients for t-values is $>2.33$, and for p-value is $<0.01$ (Hair et al., 2017). The significance of direct effect - path coefficients are presented in Table 10 below:

The above-mentioned t-value is also demonstrated in Figure 2 below:

This study evaluates the significant effects of the model of research. It is demonstrated by results that mean of the original sample is 0.458 , which is positive, $\mathrm{t}$-value is 5.999 , which is greater than 2.33 , and p-value is 0.00 , which is less than 0.01 . Hence it is established that MCG is positively statistically significant and influencing 
TABLE 10: Significance of Direct Effect - Path Coefficients.

\begin{tabular}{|c|c|c|c|c|c|c|}
\hline \multirow[t]{2}{*}{ Path } & \multirow[t]{2}{*}{ Std. Beta } & \multirow[t]{2}{*}{$\begin{array}{l}\text { Standard } \\
\text { Deviation }\end{array}$} & \multirow[t]{2}{*}{ t-value } & \multicolumn{2}{|c|}{$\begin{array}{l}\text { Confidence interval } \\
\text { bias corrected }\end{array}$} & \multirow[t]{2}{*}{ Decision } \\
\hline & & & & $5 \%$ & $95 \%$ & \\
\hline $\mathrm{MCG} \rightarrow \mathrm{FAD}$ & .458 & .076 & 5.999 & 0.367 & 0.617 & Supported \\
\hline \multicolumn{7}{|c|}{ Note: ${ }^{*} p<0.01$} \\
\hline \multicolumn{7}{|c|}{ Source: Authors' own work } \\
\hline
\end{tabular}

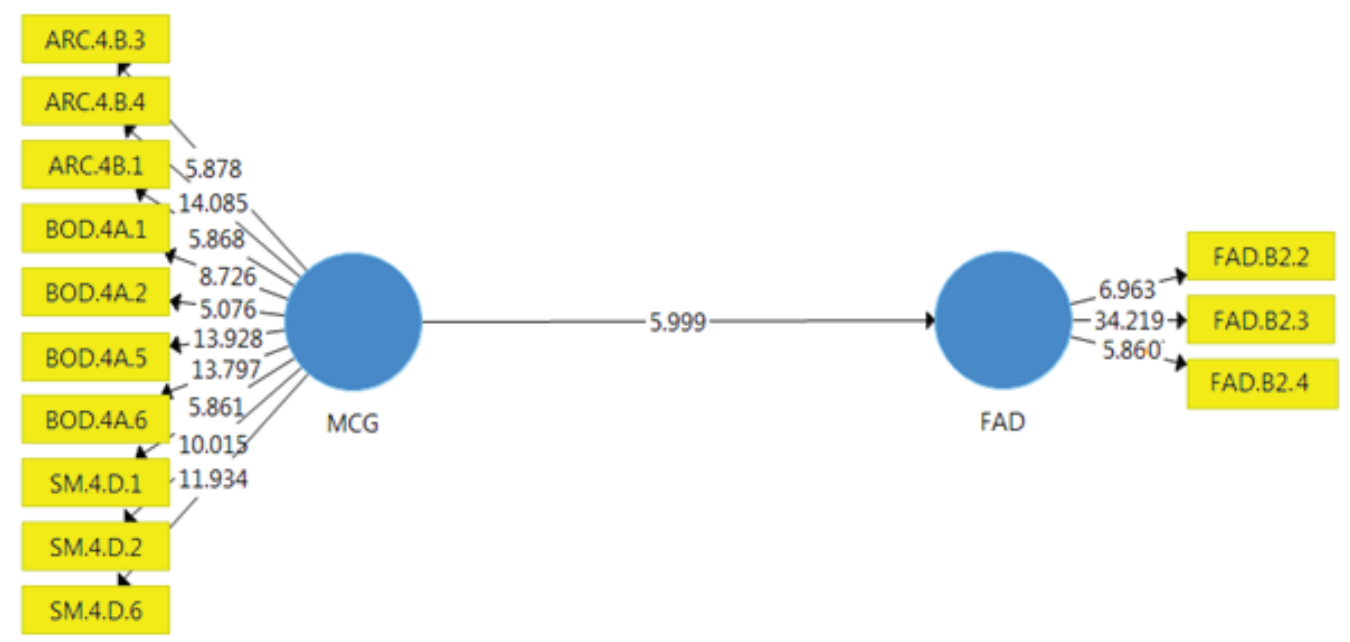

Figure 2: t-value (Source: Authors' own work).

FAD. This result is consistent with the literature review where MCG can influence FAD in the shape of policies and procedures by enforcing fraud-related controls and including FAD in reshaping corporate governance.

\section{Discussion}

Fraud is the menace which can occur in any organization. It brings not only financial losses but also damages the reputation of the organization. It is also a fact that despite the availability of many governance authorities and codes, fraud is still transpiring and with more intensity than before. Organizations are required to provide much more security to their stakeholders, especially the shareholders, as they are the major investors and one of the major affectees due to fraud.

In validation to Agency Theory, FAD is an activity that can be available within an organization which can be positively impacted by the constituents of MCG. FAD can provide detective measures to detect any fraud, identify its root cause, and can also develop controls which can prevent and mitigate fraud. FAD can be considered as governance management system by including it in the codes of corporate governance. 
Majority of the respondents agreed that they have accounting and internal control system to detect fraud however $20 \%$ of the respondents mentioned that they do not have accounting controls and $21 \%$ of respondents stated that they do not have internal controls to detect fraud. $62 \%$ of respondents agreed that FAD could only be used to uncover diverted/ unfocused fraudulent practices. However, $28 \%$ of the respondents believe that FAD can only be utilized towards uncovering fraud. As stated earlier, FAD is an activity which can develop control towards mitigation of fraud, and the majority of the respondents agree to that, moreover FAD can also develop policies and can also be part of governance management.

BOD are appointed by shareholders to run the organization on their behalf. BOD plays major role in shaping organizational strategy and performance. BOD's effectiveness is supported by its meeting. $78 \%$ of the respondents agree that in their organization, there is a defined management structure supported by organization charts for all roles. Moreover, $87 \%$ responded that BOD's meetings are held regularly and minuted, with actions noted under new codes of corporate governance issued by the Capital Market Authority. Majority of the respondents agreed that BOD is operated under their own terms of reference which is updated periodically moreover BOD also ensures that strategic planning is aligned with organizational objective. However, and as mentioned earlier, fraud is the highest risk which can distort organizational performance and achievement of its objective unless it is controlled and detected by an expert which is FAD.

ARC is appointed by BOD and operates under its terms of reference or charters. ARC provides recommendations for control enhancement and also provides assurance towards the risk that an organization can face. It is one of the duties of ARC to discuss the audit findings and related recommendation with SM of the organization. Majority of the respondents agree that ARC meetings are effective and minuted. Moreover, ARC ensures that strategic planning is in line with the organization's objectives. However, only $53 \%$ of respondents informed that ARC discusses the pervasiveness of audit finding/ recommendations in audit reports with senior management. ARC plays a vital role in controlling and eliminating fraud. ARC can assist FAD by endorsing the recommendations raised by FAD towards fraud risk and fraud controls.

SM is appointed by BOD and plays major and vital role towards implementation of policies approved by BOD. SM is the critical component for the achievement of MCG, and they are the main drivers of strategic plans. Majority of the respondents agree that they have strategic plans which last more than three years, which means that it is not rapidly changing and SM seriously views corrective actions as an avenue for improvements. 
FAD can provide corrective actions in the shape of reports and recommendations which can assist in eliminating fraud and its related risk.

FAD, if included, as an agent in governance management and supported by the major constituents of MCG, can create a difference in the field of fraud detection and control. As mentioned earlier, conventional auditors denied the role of detection of fraud, which has created the expectation gap for the shareholders. The FAD is the best option available which can not only detect fraud but at the same time assists the organization in achieving its goals and objectives.

\section{Conclusion and Implications}

Forensic accounting detective role (FAD) can be considered as the cornerstone of mature corporate governance and an agent which is necessary to eliminate the fraud within an organization. The FAD is an activity which should be available as governance management and within the organization. FAD, if supported and included, can identify the fraud, a person conducts the fraud, its basis, and reason and can mitigate its effect by developing controls. On the other hand, MCG can function effectively and can provide satisfaction to shareholders once the organization is free from fraud and fraudulent activities. MCG in this study is measured by its three major constituents namely board of director (BOD), audit and risk committee (ARC) and senior management (SM).

This study is conducted with the viewpoint that MCG has a positive impact on FAD within Omani public listed companies. For this reason, a quantitative survey is conducted for all 115 organizations listed in the Muscat Stock Market. Data is received from 110 companies from which three are further deleted for not providing the answers for all questions. The questionnaire is forwarded to all those individuals who can respond on behalf of the organization such as the BOD and related committees members and SM. Data is collected via the internet-based tool and analyzed by utilization of PLS-SEM. The result of this study suggests that MCG is having a significant direct relationship with FAD as $t$ value is above 2.33 , and the $p$-value is below 0.01 .

This study contributes towards literature review and provides practical application to organizations not only in Oman but can also be suitable for all organizations across the globe, including both public and private organizations. MCG is the essential requirements for all organizations and cannot be limited only to public listed companies. Likewise, fraud is also impacting all organizations regardless of their categorization; therefore, FAD is essential towards elimination, mitigation, and controlling of fraud. 
In accordance with the literature review and result of research, it is highly recommended that organizations should have FAD as fraud detecting control and should be embedded it in their corporate governance policies which will eventually be impacted by MCG.

\section{References}

[1] Abbot, L., Park, Y., \& Parker, S. (2000). The effects of audit committee activity and independence on corporate fraud: Managerial Finance. 26 (11), 55-68.

[2] Abdullah, H., Valentine, B. (2009). Fundamental and ethics theories of corporate governance: Middle Eastern Finance and Economics. 4, 88-96.

[3] ACFE. (2012). Report to the nations on occupational fraud and abuse. Chicago: Association of Certified Fraud Examiners.

[4] ACFE. (2014). Report to the nations on occupational fraud and abuse. Chicago: Association of Certified Fraud Examiners.

[5] ACFE. (2016). Report to the nations on occupational fraud and abuse. Chicago: Association of Certified Fraud Examiners.

[6] Adrian, N. K., Lawrence, A., \& Cristal Lee, A. S. (2009). Forensic Accounting: Public Acceptance towards Occurrence of Fraud Detection: International Journal of Business Management. 4 (11), 145-149.

[7] AICPA. (2017). Practice Aid: Audit and Accounting Manual. New York: American Institute of Certified Public Accountants.

[8] AICPA. (2013). Generally Accepted Accounting Standards. AICPA.

[9] Afza, T., \& Nazir, M. S. (2014). Theoretical perspective of corporate governance: A Review: European Journal of Scientific Research. 119 (2), 255-264.

[10] Allais, R., Roucoules, L., \& Reyes, T. (2016). Governance maturity grid: a transition method for integrating sustainability into companies: Journal of Cleaner Production. 140, 213-226.

[11] Al-Shammari, B., Brown, P., \& Tarca, A. (2008). An Investigation of Compliance with International Accounting Standards by Listed Companies in The Gulf Co-Operation Council Member States: The International Journal of Accounting. 43(4), 425-447.

[12] Baatwah, S. R., Salleh, Z., \& Ahmad, N. (2015). Corporate governance mechanisms and audit report timeliness: empirical evidence from Oman: International Journal of Accounting, Auditing and Performance Evaluation. 11 (3/4), 312-337.

[13] Baghel, I., \& Yadav, S. N. (2009). Good governance, Issues, challenges, and prospects. Global Vision publishing house. 
[14] Bahrman, D., Manchanda, A., Roth, J., \& Mendes, M. (2012). IIA Research Foundation, IIARF [Online]. Available from na.theiia.org: https://na.theiia.org/standards-guidance/Member[\%]20Documents/PG\{\%\}20-

\{\%\}20Assessing\{\%\}20Organizational\{\%\}20Governance[\%\}20in\{\%]20the\{\%]20Private\{\%\}20Se pdf

[15] Bansal, N., \& Sharma, A. K. (2016). Audit Committee, Corporate Governance and Firm Performance: Empirical Evidence from India: International Journal of Economics and Finance. 8 (3), 103-116.

[16] Baydoun, N., Maguire, W., Ryan, N., \& Willett, R. (2013). Corporate governance in five Arabian Gulf countries. Managerial Auditing Journal. 28 (1), 7-22.

[17] Bentley-Goode, K. A., Newton, N. J., \& Thompson, A. M. (2017). Business Strategy, Internal Control over Financial Reporting, and Audit Reporting Quality American Accounting Association, Auditing: A Journal Of Practice \& Theory. 36 (4), 49-69.

[18] Berenson, R. A. (2016). If You Can't Measure Performance, Can You Improve It? The JAMA Forum. 315 (7), 645-646.

[19] Bhasin, M. L. (2013). Corporate Governance and Forensic Accountant: an Exploratory Study: Journal of Accounting - Business \& Management. 20 (2), 55-83.

[20] Bramont, P. (2012). Maturidade em governança corporativa: diretrizes para um modelo preliminar. (PhD Thesis Universidade Catolica de Brasilia,. Brazil). [Online] Available from https://bdtd.ucb.br:8443/jspui/bitstream/123456789/1374/1/ Pedro\{\%\}20Bramont.pdf

[21] Brender, N., Yzeiraj, B., \& Fragniere, E. (2015). The management audit as a tool to foster corporate governance: an inquiry in Switzerland: Managerial Auditing Journal. $30(8 / 9), 785-811$.

[22] Butt, I. H., \& Shams, J. A. (2013). Master in Education Student Attitudes towards Research: A Comparison between two Public Sector Universities in Punjab: $A$ Research Journal of South Asian Studies. 28 (1), 97-105.

[23] Butt, S. a. (2012). Corporate Governance. Farooq Printing Press.

[24] Charles, D., Ramona, F., \& Suzanne, O. (2009). Characteristics and Skills of the Forensic Accountant. American Institute of Certified Public Accountants: The Forensic and Valuation Service Section.

[25] CMA. (2016). Oman Code of Corporate Governance for Public Listed Companies. Capital Market Authority.

[26] Deloitte, T. (2010). The centre for corporate governance: Board Leadership. Deloitte \& Touche LLP Internal Audit Professionals. 
[27] Ellen, K. D. (2002). Corporate Governance in Sultanate Oman. [Online] Available from http://rjglb.richmond.edu/wp-content/uploads/2013/03/rgl_3-1_dry.pdf

[28] Enofe, A., Julius, O., \& Ogbeide, O. (2015). The Role of Forensic Accounting in Combating Financial Crimes: Research Journal of Finance and Accounting. 6 (18), 191-199.

[29] Fernando, A. (2009). Corporate Governance: Principles, Policies and Practices. Pearson

[30] Francine, M. (2018). FDIC wins against PWC could finally force auditors to look for fraud. [Online] Available from www.marketwatch.com.

[31] Ganesan, Y., Hwa, Y. W., Jaaffar, A. H., \& Hashim, F. (2017). Corporate Governance and Sustainability Reporting Practices: The Moderating Role of Internal Audit Function: Global Business \& Management Research. Special issue. 9, 159-179.

[32] García-Carbonell, N., Martín-Alcázar, F., \& Sánchez-Gardey, G. (2015). Determinants of top management's capability to identify core employees: $B R Q$ Business Research Quarterly. 18 (2), 69-80.

[33] Gee, S. (2014). Fraud and Fraud Detection: A Data Analytics Approach. New Jersey: John Wiley \& Sons, Inc., Hoboken, New Jersey.

[34] Hair, J. F., Hult, G. T., Ringle, C. M., \& Sarstedt, M. (2017). A Primer on Partial Least Squares Structural Equation Modeling (PLS-SEM), 2nd Ed. Sage.

[35] Hermanson, H. M., \& Rama, D. B. (2016). Pressure on Internal Auditors to Alter Findings: Journal of Forensic \& Investigative Accounting. 8 (3), 428-443.

[36] Harpham, T., Grant, E., \& Thomas, E. (2002). Measuring Social Capital Within Health Survey: Key Issues. Health Policy and Planning. 17(1), 106-111.

[37] Hashim, F., Mahadi, N. D., \& Amran, A. (2015). Corporate Governance and Sustainability Practices in Islamic Financial Institutions: The Role of Country of Origin. Paper presented at International Accounting And Business Conference: Procedia Economics and Finance. 31, $36-43$.

[38] Henseler, J., Ringle, C., \& Sarstedt, M. (2015). A new criterion for assessing discriminant validity in variance-based structural equation modeling: Journal of the Academy of Marketing Science. 43 (1), 115-135.

[39] Homayara, L. A., Md. Jahangir, A., Saeed, A. J., \& Sawlat, H. Z. (2008). A Conceptual Review on Corporate Governance and its Effect on Firm's Performance: Bangladesh Perspective: AIUB Bus Econ Working Paper Series. [Online] Availble from http://orp. aiub.edu/WorkingPaper/WorkingPaper.aspx?year=2008, 1-24.

[40] IIA, I. o. (2016). Internal Auditing and Fraud. The Institute of Internal Auditors-IPPF Practice Guide. 
[41] Janulyte, V., Aleksejuniene, J., Puriene, A., Peciuliene, V., \& Benzian, H. (2014). Current employment characteristics and career intentions of Lithuanian dentists. Human Resources for Health. https://doi.org/10.1186/1478-4491-12-74.

[42] Keasey, K., Thomson, S., \& Right, M. (2012). Corporate governance, economic, management and financial issues. Oxford press University.

[43] Kocmanova, A., \& Simberova, I. (2012). Modelling of CorporateGovernance Performance Indicators: Inzinerine Ekonomika-Engineering Economics. 23 (5), 485495.

[44] Korb, K. A. (2016). [Online] Available from http://korbedpsych.com/index.html:

[45] Korine, H., \& Gomez, Y. P. (2014). Strong managers, strong owners: Corporate Governance and Strategy. Cambridge University Press.

[46] Laux, C., \& Laux, V. (2009). Board committees, CEO compensation, and earnings management: The Accounting Review. 84, 869-891.

[47] Leonard, W. V. (2010). The Fraud Audit: Responding to the Risk of Fraud in Core Business Systems. John Wiley and Sons Ltd.

[48] Lockhart, J. (2011). Governance of the Economic Engine Room: Insights From Agricultural Governance in New Zealand: Proceedings of the European Conference on Management, Leadership \& Governance. 254-261.

[49] Massie, R. (2012). Key Identifiers of Corporate Governance Maturity: A Literature Review: 10th European Academic Conference on Internal Audit and Corporate Governance. Verona: University of Verona, Verona, Italy

[50] Meeran, S. K., Amjad, C. M., Ansari, M. I., Ansari, M. S., \& Latif, A. (2018). Role and challenges of hospital pharmacists working in Liaquat university hospital hyderabad/ jamshoro, a public Sector hospital, Pakistan: JUMDC. 9 (1), 33-43.

[51] Mohd-Sanusi, Z., Rameli, M. N., Omar, N., \& Ozawa, M. (2015). Governance Mechanisms in the Malaysian Banking Sector: Mitigation of Fraud Occurrence: Asian Journal of Criminology. 10 (3), 231-250.

[52] Nigrini, M. J. (2012). Benford's Law Applications for Forensic Accounting, Auditing, and Fraud Detection. John Wiley \& Sons, Inc., Hoboken, New Jersey

[53] O'Connell, D. (2016). Measuring corporate governance maturity: Evidence from the NSW public sector. Sydney: Governance Directions; Sydney Harbour Foreshore Authority.

[54] O'Connor, T., \& Byrne, J. (2015). Governance and the corporate life-cycle: International Journal of Managerial Finance. 11 (1), 23-43.

[55] Odelabu, A. (2016). Relationship between Forensic Accountants' Competences and Audit Expectation Gap: Evidence from Nigeria Money Deposit Banks.. (PhD Thesis, 
Jomo Kenyatta University of Agriculture and Technology, Kenya.). [Online]. Available from http://hdl.handle.net/123456789/2195.

[56] OECD. (2009). Corporate Governance and the Financial Crisis: Key Findings and Main Messages. Organisation for economic co-operation and development.

[57] Oso, L., \& Semiu, B. (2012). The Concept and Practice of Corporate Governance in Nigeria: The Need for Public Relations and Effective Corporate Communication: Kamla-Raj Communication. 3 (1), 1-16.

[58] Pedneault, S., Rudewicz, F., \& Silverstone, H. (2012). Forensic Accounting and Fraud Investigation for Non-Experts . New Jersey: John Wiley \& Sons, Inc., Hoboken.

[59] Pintea, M. O., \& Fulop, M. T. (2015). Corporate Governance - Key Factor To Enhance Performance: Managerial Challenges of the Contemporary Society. 8 (2), 116-120.

[60] Portella, G. (2014). Assessing Organizational Governance in the Public Sector. [Online] Available from www.na.theiia.org: https://na.theiia.org/standards-guidance/Member\{\%]20Documents/ PG\{\%\}20Assessing\{\%\}20Organizational\{\%\}20Governance\{\%\}20in\{\%\}20the\{\%\}20Public\{\%\}20 pdf

[61] Pretorius, H. W. (2015). Towards a Theoretical Framework to Support Corporate Governance through the use of a Business Process Management System: A South African Perspective.(PhD Thesis:University of Pretoria; South Africa.).[Online] Available from https://repository.up.ac.za/handle/2263/40824

[62] Ramayah, T., Cheah, J., Chuah, F., Ting, H., \& Mumtaz A., M. (2016). Partial Least Squares Structural Equation Modeling (PLS-SEM) Using SmartPLS 3.0: An Updated Guide and Practical Guide to Statistical Analysis. Kuala Lumpur, Malaysia: Pearson.

[63] Rehman, A., \& Hashim, F. (2018). Literature review: Preventive Role of Forensic accounting and Corporate Governance Maturity. Journal of Governance and Integrity (JGI), 1 (2), 68-93.

[64] Reuter, S. (2013). Oman's Bank Muscat hit by $\$ 39 \mathrm{mln}$ prepaid card fraud. [Online] Available from https://www.reuters.com/article/oman-bankmuscat-fraud/ omans-bank-muscat-hit-by-39-mln-prepaid-card-fraud-idUSL6NOBQ1C720130226

[65] Reuters, S. (2011). Oman's Renaissance uncovers fraud at Topaz unit, $\mathrm{H} 1$ profit falls. [Online] Available from https://www.reuters.com/article/usrenaissance-results/omans-renaissance-uncovers-fraud-at-topaz-unit-h1-profitfalls-idUSTRE77EONW20110815

[66] Reuters, S. (2014). Oman court jails businessman to 15 years over bribes. [Online] Available from https://www.reuters.com/article/us-oman-corruption-sentences/ oman-court-jails-businessman-to-15-years-over-bribes-idUSBREA280I020140309 
[67] Reuters, S. (2014). Omani CEO jailed for 23 years in graft case: court. [Online] Available from https://www.reuters.com/article/us-oman-corruption-sentences/omaniceo-jailed-for-23-years-in-graft-case-court-idUSBREA1Q1OW20140227

[68] Roberta, R., Sanjai, B., \& Brian, B. (2008). The Promise and Peril of Corporate Governance Indices. [Online] Available from www.yale.edu:http://digitalcommons. law.yale.edu/cgi/viewcontent.cgi?article=2970\&context=fss_papers

[69] Salem, M. S. (2012). An Overview of Research on Auditor's Responsibility to Detect Fraud on Financial Statements: The Journal of Global Business Management. 8 (2), 218-229.

[70] Samim, F., Aleksejuniene,J., Zed, C., Salimi, N., \& Emperumal, C. P. (2013) Dental Treatment Needs in Vancouver Inner-City Elementary School-Aged Children, International Journal of Dentistry, vol. 2013, Article ID 602791. https://doi.org/10.1155/ 2013/602791.

[71] Sanyal, S., \& Hisam, M. W. (2018). Corporate Governance In Emerging Economies: A Study Of The Sultanate of Oman. International Journal of Business and Administration Research Review. 3 (20), 27-31

[72] Shehata, N. F. (2015). Development of corporate governance codes in the GCC: an overview: Corporate Governance. 15 (3), 315-338.

[73] Shir, L. N. (2013). Role Effectiveness of Audit Committees' Governance Characteristics: Impacts on Internal and External Auditing of Listed Companies. (PhD Thesis, School of Accounting College of Business RMIT University, Australia). [Online] Available from https://researchbank.rmit.edu.au/view/rmit:160435

[74] Singleton, T., \& Singleton, A. (2010). Fraud Auditing and Forensic Accounting 4th Edition. Chicago: John Wiley \& Sons.

[75] Siregar, S. V., \& Tenoyo, B. (2015). Fraud awareness survey of private sector in Indonesia: Journal of Financial Crimes. 22 (3), 329-346.

[76] Vinita, R., Joe, U. C., \& Lee, C. (2008). Corporate Governance Characteristics of Growth Companies: An Empirical Study: Academy of Strategic Management Journal. 7, 21-33.

[77] Wilkinson, N. (2014, March). A framework for organizational governance maturity: an internal audit perspective. South Africa: (PhD Thesis, University of Pretoria. South Africa). [Online] Available from https://repository.up.ac.za/bitstream/handle/ 2263/43563/Wilkinson_Framework_2014.pdf;sequence=4

[78] Wilkinson, N., \& Plant, K. (2012). A framework for the development of an organisational governance maturity model: a tool for internal auditors: Southern African Journal of Accountability and Auditing Research. 13, 19-31. 
[79] Yeboah, E. B., Kwafoa, P., \& Amoah, G. B. (2017). Security of Staff in Academic Libraries: A Study of Sam Jonah Library, University of Cape Coast: Journal of Applied Information Science. 5 (1), 1-6.

[80] Yılmaz, i. (2018). Corporate Governance and Financial Performance Relationship: Case for Omani Companies: Journal of Accounting, Finance and Auditing Studies. 4/4, 84-106.

[81] Zakaria, N. B. (2012). Corporate Governance And The Relationship Between Default Risk And The Earnings Response Coefficient. (PhD thesis Victoria University of Wellington, New Zealand): Retreived from http://researcharchive.vuw.ac.nz/ bitstream/handle/10063/2106/thesis.pdf?sequence=1.

[82] Zhu, P. (2016). Digitizing Boardroom: The Multifaceted Aspects of Digital Ready Boards. Book Bay. 